\title{
Pyrophosphorolysis-Activated Polymerization (PAP): Application to Allele-Specific Amplification
}

BioTechniques 29:1072-1083 (November 2000)

\author{
Qiang Liu and Steve S. \\ Sommer \\ City of Hope National Medical \\ Center, Duarte, CA, USA
}

\section{ABSTRACT}

To measure mutation load or to detect minimal residual disease, a robust method for identifying one mutant allele in the range of $10^{6}-10^{9}$ wild-type alleles would be advantageous. Herein, we present evidence that pyrophosphorolysis-activated polymerization (PAP) has the potential to provide a highly specific and robust method of allelespecific amplification if DNA polymerases with higher pyrophosphorolysis activity can be found or engineered. In PAP, pyrophosphorolysis and polymerization by DNA polymerase are coupled serially by utilizing a pyrophosphorolysis-activatable oligonucleotide $\left(P^{*}\right) . P^{*}$, which is an allele-specific oligonucleotide with a dideoxynucleotide at the $3^{\prime}$ terminus, can be activated by pyrophosphorolysis to remove the $3^{\prime}$ terminal dideoxynucleotide in the presence of pyrophosphate $\left(P P_{i}\right)$ and the complementary strand of the allelic template; then the activated $P^{*}$ can be extended by DNA polymerization. Specificity results from both pyrophosphorolysis and polymerization because significant nonspecific amplification requires the combination of mismatch pyrophosphorolysis and misincorporation by the DNA polymerase, which is an extremely rare event. Proof of principle has been achieved with a polymorphic site within the human $D_{1}$ dopamine receptor gene. The effects of the dideoxyoligonucleotide sequences, DNA polymerases, $P P_{i}$ concentrations, allele-specific templates, $p H$ and dNTP concentrations were examined.

\section{INTRODUCTION}

A method of detecting one mutant allele in $10^{6}-10^{9}$ wild-type alleles would be advantageous for many applications including detecting minimal residual disease (rare remaining cancer cells during remission, especially mutations in the $p 53$ gene or other tumor suppressor genes previously identified within the tumors) and measurement of mutation load (the frequency of specific somatic mutations present in normal tissues such as blood or urine). Individuals with a high mutation load may be at increased risk for cancer due to either environmental exposure or endogenous defects in any of the hundreds of genes necessary to maintain the integrity of the genome. For those individuals found to have a high mutation load, clues to etiology can be obtained by defining the mutation pattern.

Multiple methods for detecting mutations present in less than $10 \%$ of cells (i.e., rare alleles) have been developed including PCR amplification of specific alleles (PASA), peptide nucleic acid (PNA) clamping blocker PCR, allelespecific competitive blocker PCR, mismatch amplification mutation assay (MAMA) and restriction fragmentlength polymorphism (RFLP)/PCR (16). These methods (i) amplify the rare allele selectively, (ii) destroy the abundant wild-type allele or (iii) spatially separate the rare allele from the wildtype allele. RFLP/PCR has been reported to have the highest specificity of $10^{-8}$ (17), but in our hands the specificity has been $10^{-3}-10^{-4}(8)$. Methods that selectively amplify the rare allele include PASA, which routinely has a specificity of less than or equal to 1 part in 40 (21).
DNA polymerases, which are critical to nucleic acid amplification, catalyze some or all of the following reactions: (i) polymerization of deoxynucleotide triphosphates; (ii) pyrophosphorolysis of duplexed DNA in the presence of pyrophosphate $\left(\mathrm{PP}_{\mathrm{i}}\right),[\mathrm{dNMP}]_{\mathrm{n}}+\mathrm{x}[\mathrm{PPi}]$ $\rightarrow[\mathrm{dNMP}]_{\mathrm{n}-\mathrm{x}}+\mathrm{x}[\mathrm{dNTP}]$; (iii) $3^{\prime} \rightarrow 5^{\prime}$ exonuclease activity; and (iv) $5^{\prime} \rightarrow 3^{\prime}$ exonuclease activity $(5,9)$. For $T a q$ and $T f l$ DNA polymerases, the polymerization and $5^{\prime} \rightarrow 3^{\prime}$ exonuclease activity have been reported $(4,7,13)$. For T7 Sequenase $^{\circledR}$ and Thermo Sequenase ${ }^{\mathrm{TM}}$ DNA polymerases (both from Amersham Pharmacia Biotech, Piscataway, NJ, USA), pyrophosphorolysis can lead to the degradation of specific dideoxynucleotide-terminated segments in Sanger sequencing reaction $(23,25)$. Herein, we describe pyrophosphorolysis-activated polymerization (PAP), an approach that has the potential to enhance dramatically the specificity of PASA.

\section{MATERIALS AND METHODS}

\section{Preparation of Template by PCR}

A 640-bp region of the human $\mathrm{D}$ dopamine receptor gene was amplified by PCR with two primers ( $\mathrm{T}=5^{\prime}$-GACCTGCAGCAAGGGAGTCAGAAG- ${ }^{\prime}$ and $\mathrm{U}=5^{\prime}$-TCATAC CGGAAAGGG CTGGAGATA-3') (Figure 1A). The TU:UT duplexed product spans nucleotides 33-672 in GenBank ${ }^{\circledR}$ accession no. X55760 and the GC content is $55.3 \%$. A common A to $\mathrm{G}$ polymorphism is located at nucleotide 229 , resulting in three genotypes of GG, AA and GA (11). The PCR mixture contained a volume of $50 \mu \mathrm{L}: 50 \mathrm{mM} \mathrm{KCl}$, 
$10 \mathrm{mM}$ Tris- $\mathrm{HCl}, \mathrm{pH} 8.3,1.5 \mathrm{mM}$ $\mathrm{MgCl}_{2}, 200 \mu \mathrm{M}$ each of the four dNTPs (Roche Molecular Biochemicals, Indianapolis, IN, USA), $0.1 \mu \mathrm{M}$ each primer, $2 \%$ dimethyl sulfoxide (DMSO), 1 U Taq DNA polymerase (Roche Molecular Biochemicals) and $250 \mathrm{ng}$ genomic DNA from GG homozygote, AA homozygote or GA heterozygotes. Cycling conditions includ- ed denaturation at $94^{\circ} \mathrm{C}$ for $15 \mathrm{~s}$, annealing at $55^{\circ} \mathrm{C}$ for $30 \mathrm{~s}$ and elongation at $72^{\circ} \mathrm{C}$ for $1 \mathrm{~min}$, for a total of $35 \mathrm{cy}$ cles (GeneAmp ${ }^{\circledR}$ PCR System 9600; Applied Biosystems, Foster City, CA, USA). The PCR product was purified from primers and other small molecules by approximately 10000 -fold by three times of retention on an Amicon ${ }^{\circledR}$ Centricon ${ }^{\circledR} 100$ microconcentrator (Milli- pore, Bedford, MA, USA). The amount of recovered PCR product was determined by UV absorbance at $260 \mathrm{~nm}$.

\section{Synthesis of a Pyrophosphorolysis- Activatable Oligonucleotide $\left(\mathrm{P}^{*}\right)$ by Adding a 3' Dideoxynucleotide}

The deoxynucleotide was synthesized by a Model 8909 Synthesizer

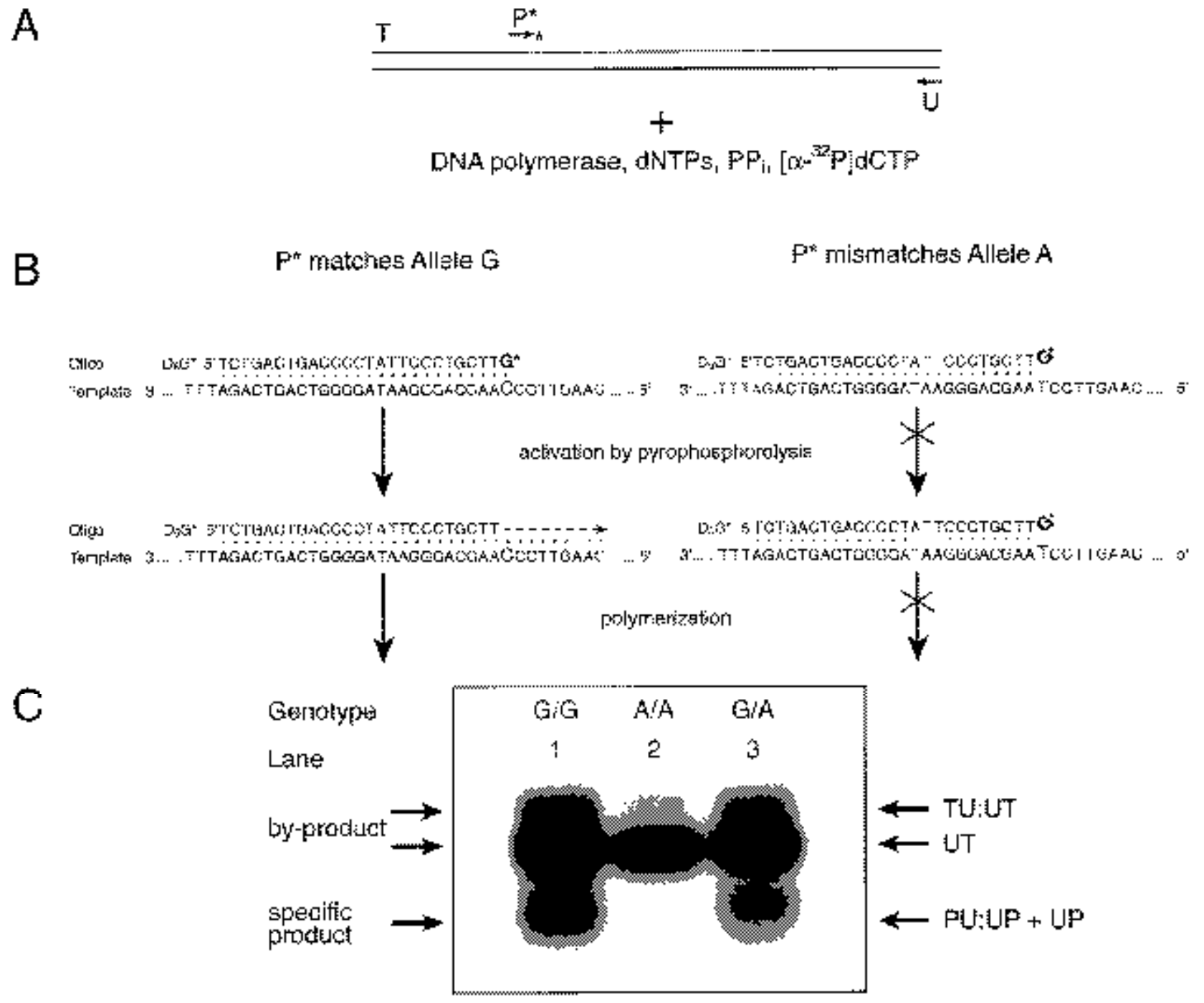

Figure 1. Schematic of PAP. (A) A duplexed DNA template TU:UT is amplified with two oligonucleotides, $\mathrm{P}^{*}$ and U, Tfl DNA polymerase, dNTPs, pyrophosphate and $\left[\alpha-3\right.$ P]dCTP. $\mathrm{P}^{*}=$ pyrophosphorolysis-activatable oligonucleotide. In this example, $\mathrm{P}^{*}$ is $\mathrm{D}_{5} \mathrm{G}^{*}$, and TU:UT is a 640-bp segment of the dopamine D1 receptor gene. (B) $\mathrm{BG}^{*}$ has a $\mathrm{G}$ dideoxynucleotide at the $3^{\prime}$ terminus, and it is specific to the complementary strand of the $\mathrm{G}$ allele but mismatches the A allele at the $3^{\prime}$ terminus (Table 1). Removal of the dideoxy $\mathrm{G}$ by pyrophosphorolysis is followed by polymerization for each amplification. (C) Autoradiogram of PAP from the GG, AA and GA genotypes. When the G allele is present, the radioactively labeled specific products of 469 bases (duplex PU:UP and excess antisense strand UP) are produced because the low rate of pyrophosphorolysis by $T f l$ polymerase implies that oligonucleotide U has a much higher efficiency than oligonucleotide P*. Electrophoresis for a longer period separates PU:UP from UP. Other products of UT and TU:UT are indicated. Note that TU:UT derives from annealing of excess radioactively labeled UT with nonradioactively labeled TU original template. 


\section{Research Report}

Table 1. Oligonucleotides Used in PAP

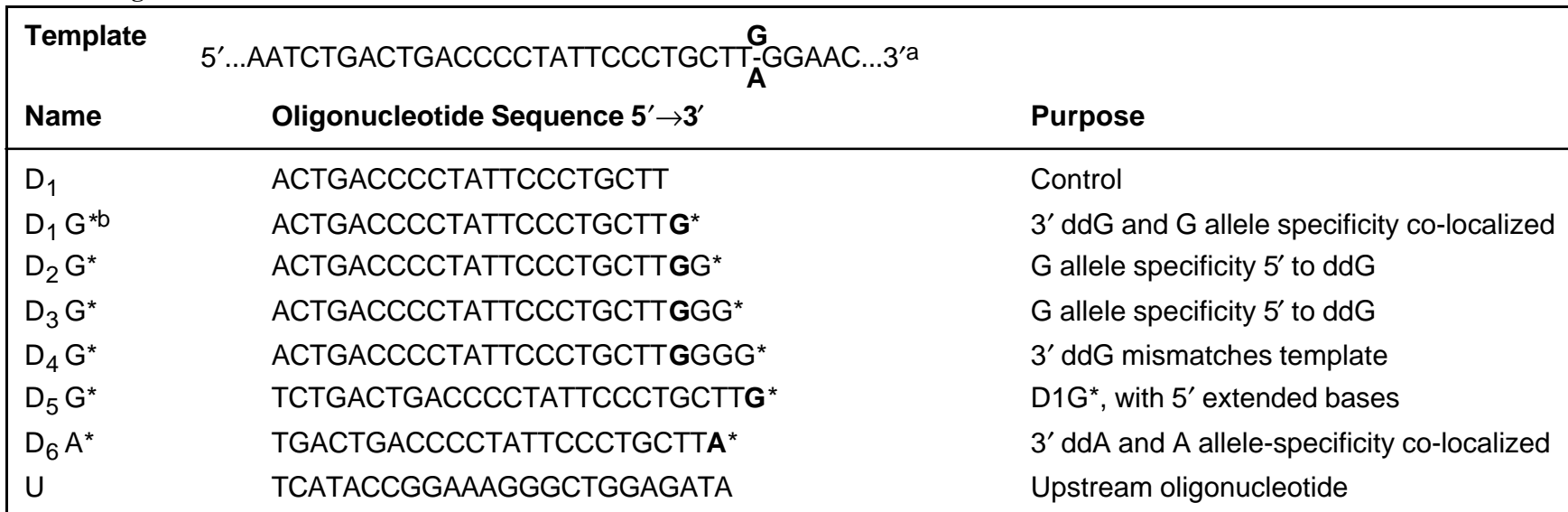

\begin{tabular}{|c|c|c|c|c|c|c|c|c|}
\hline \multirow[b]{2}{*}{ Name } & \multicolumn{2}{|c|}{$\begin{array}{l}3^{\prime} \text { Terminal } \\
\text { Nucleotide }^{c}\end{array}$} & \multicolumn{2}{|c|}{$\begin{array}{l}\text { Allele-Specific } \\
\text { Nucleotided }^{d}\end{array}$} & \multirow[b]{2}{*}{$\begin{array}{c}\text { Size } \\
\text { (base) }\end{array}$} & \multirow[b]{2}{*}{$\begin{array}{c}\mathrm{T}_{\mathrm{m}} \\
\left({ }^{\circ} \mathrm{C}\right)^{\mathrm{e}}\end{array}$} & \multicolumn{2}{|c|}{ Amplification $f$} \\
\hline & Type & Match & Type & $\begin{array}{c}\text { From 3' } \\
\text { Terminus (bp) }\end{array}$ & & & G allele & A allele \\
\hline $\mathrm{D}_{1}$ & dT & Yes & - & +1 & 21 & 64 & Yes & Yes \\
\hline$D_{1} G^{*}$ & $d d G$ & Yes & $G$ & 0 & 22 & 68 & No & No \\
\hline$D_{2} G^{*}$ & $d d G$ & Yes & $G$ & -1 & 23 & 72 & No & No \\
\hline$D_{3} G^{*}$ & $d d G$ & Yes & $G$ & -2 & 24 & 76 & Yes & No \\
\hline $\mathrm{D}_{4} \mathrm{G}^{*}$ & $d d G$ & No & $G$ & -3 & 25 & 80 & No & No \\
\hline $\mathrm{D}_{5} \mathrm{G}^{*}$ & $d d G$ & Yes & $G$ & 0 & 26 & 80 & Yes & No \\
\hline$D_{6} A^{*}$ & $d d A$ & Yes & A & 0 & 24 & 72 & No & No \\
\hline$U$ & $d A$ & Yes & - & - & 24 & 72 & Yes & Yes \\
\hline
\end{tabular}

aThe bold $\mathbf{G}$ and $\mathbf{A}$ correspond to the $\mathbf{G}$ and $A$ alleles, respectively.

${ }^{b} D_{1} G^{*}=D_{1}$ with ddG to the $3^{\prime}$ terminus; * denotes a dideoxynucleotide at the $3^{\prime}$ terminus. The first base at the $5^{\prime}$ terminus corresponds to nucleotide 208 in GenBank accession no. X55760.

'The $3^{\prime}$ terminal base is a deoxynucleotide or dideoxynucleotide and creates a match (Yes) or a mismatch (No) with the corresponding base on the complementary strand of the template.

dThe allele-specific nucleotide is $\mathrm{G}$ or $\mathrm{A}$, and its distance to the $3^{\prime}$ terminus is assigned: $0=$ at the $3^{\prime}$ terminus; $+1=1$ base downstream from the $3^{\prime}$ terminus; $-1=1$ base upstream from the $3^{\prime}$ terminus; $-2=2$ bases upstream from the $3^{\prime}$ terminus and $-3=3$ bases upstream from the $3^{\prime}$ terminus.

eThe $T_{m}$ for oligonucleotides was estimated to be $4^{\circ} \mathrm{C} \times(\mathrm{G}+\mathrm{C})+2^{\circ} \mathrm{C} \times(\mathrm{T}+\mathrm{A})$ at $1 \mathrm{M} \mathrm{NaCl}(15)$.

${ }^{f}$ Amplification with $U$ and one $P^{*}$ or with only one $P^{*}$.

(PerSeptive Biosystems, Framingham, MA, USA) and purified by oligopure cartridges (Hamilton, Reno, NV, USA) in the City of Hope DNA/RNA Chem istry Laboratory. The $3^{\prime}$ terminal dideoxynucleotide was added by terminal transferase. The mixture contained a total volume of $40 \mu \mathrm{L}: 200 \mathrm{mM}$ potassium cacodylate, $25 \mathrm{mM}$ Tris- $\mathrm{HCl}(\mathrm{pH} 6.6$ at $\left.25^{\circ} \mathrm{C}\right), 2.5 \mathrm{mM} \mathrm{CoCl} 2,0.25 \mathrm{mg} / \mathrm{mL}$ $\mathrm{BSA}, 4000 \mathrm{pM}$ of the oligonucleotide, $2.5 \mathrm{mM} 2^{\prime}, 3^{\prime}$-ddNTP (the molar ratio of the $3^{\prime} \mathrm{OH}$ terminus to ddNTP was 1:25), $125 \mathrm{U}$ terminal transferase (the last two items are both from Roche Molecular Biochemicals). The reaction was incubated at $37^{\circ} \mathrm{C}$ for $1 \mathrm{~h}$ and then stopped by adding EDTA at $5 \mathrm{mM}$ final concentration. After desalting by using butanol, the dideoxyoligonucleotide was purified by preparative $7 \mathrm{M}$ urea/20\% polyacrylamide gel electrophoresis (PAGE) in TBE buffer (90 mM Tris-borate, $1 \mathrm{mM}$ EDTA, pH 8.3) (14). The amount of the recovered $\mathrm{P}^{*}$ was determined by UV absorbance at $260 \mathrm{~nm}$.

Since small amounts of unterminated oligonucleotide would result in nonspecificity of pyrophosphorolysis, each dideoxyoligonucleotide was 32P-labeled at the $5^{\prime}$ terminus by T4 polynucleotide kinase and then was electrophoresed through a $7-\mathrm{M}$ urea/20\% polyacrylamide gel. Only $\mathrm{P} *$ products were visible even when the gel was overexposed (data not shown). It is 


\section{Research Report}

estimated that more than $99.99 \%$ of $\mathrm{P}^{*}$ contained a dideoxynucleotide at the $3^{\prime}$ terminus. The purity of $\mathrm{P}^{*}$ was supported by the absence of PCR product or PAP product at $\mathrm{pH} 8.1$ (Table 2).

\section{PAP}

A 469-bp region within the TU:UT duplexed template was amplified by PAP with oligonucleotides $\mathrm{P}^{*}$ and $\mathrm{U}$ or with only $\mathrm{P}^{*}$ (Table 1 and Figure 1A). The PU:UP duplexed product corresponds to nucleotides 204-672 in GenBank accession no. X55760, and the GC content is $55.6 \%$. Unless stated, the PAP reaction mixture contained a total volume of $25 \mu \mathrm{L}$ for $T f l$ DNA polymerase: $75 \mathrm{mM} \mathrm{KCl}, 20 \mathrm{mM}$ Tris- $\mathrm{HCl}$ ( $\mathrm{pH} 7.4), 1.5 \mathrm{mM} \mathrm{MgCl}_{2}, 40 \mu \mathrm{M}$ each of the four dNTPs (dATP, dTTP, dGTP and dCTP), $0.2 \mu \mathrm{M} \mathrm{P} *, 0.05 \mu \mathrm{M} \mathrm{U}$ oligonucleotide, $300 \mu \mathrm{M} \mathrm{Na} 4 \mathrm{PP}_{\mathrm{i}}$ (the $20 \mathrm{mM}$ stock solution was adjusted by $\mathrm{HCl}$ to $\mathrm{pH} 8.0), 1 \mu \mathrm{Ci}\left[\alpha-{ }^{32} \mathrm{P}\right] \mathrm{dCTP}$ (3000 Ci/mmol; Amersham Pharmacia Biotech), 1 U Tfl DNA polymerase
(Promega, Madison, WI, USA) and 2 ng TU:UT. For Taq DNA polymerase, the reaction mixture was the same except for $50 \mathrm{mM} \mathrm{KCl}, 10 \mathrm{mM}$ Tris- $\mathrm{HCl}$ (pH 7.4), $2.0 \mathrm{mM} \mathrm{MgCl}_{2}$ and $1 \mathrm{U}$ Taq DNA polymerase. The mixtures of PCR and other controls were the same except for the primers added. Cycling conditions included: $94^{\circ} \mathrm{C}$ for $15 \mathrm{~s}, 55^{\circ} \mathrm{C}$ for $1 \mathrm{~min}$, ramping to $72^{\circ} \mathrm{C}$ for $1 \mathrm{~min}$ and $72^{\circ} \mathrm{C}$ for $2 \mathrm{~min}$, for a total of 15 cycles.

The reaction was electrophoresed through a standard $2 \%$ agarose gel. The gel was stained with ethidium bromide for UV photography by a charge-coupled device (CCD) camera (Gel Doc 1000; Bio-Rad Laboratories, Hercules, CA, USA), dried and subjected to XOMAT $^{\mathrm{TM}}$ AR film (Eastman Kodak, Rochester, NY, USA) for autoradiography.

\section{Restriction Digestion}

Each of three restriction endonucleases of AciI $\left(5^{\prime}-\mathrm{C} \downarrow \mathrm{CGC}-3^{\prime} / 3^{\prime}-\mathrm{GGC} \uparrow\right.$ G-5'), EaeI (5'-Py $\downarrow$ GGCCPu-3'/3'-PuCCGG'Py-5') and Eco0109I ( $5^{\prime}-\mathrm{PuG} \downarrow$

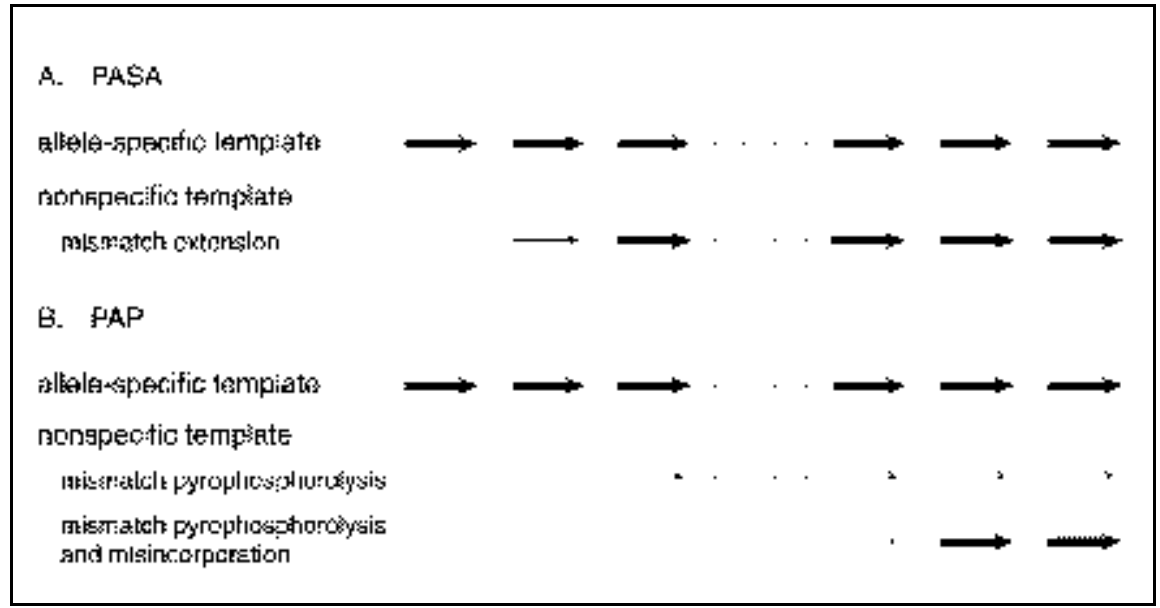

Figure 2. Enhanced specificity of PAP with $\mathbf{R G}^{*}$. The specificity of PAP is compared with that of PASA to exponentially amplify a template pool of $G$ and A alleles. (A) The specific amplification of PASA derives from the high efficiency of primer extension when the primer matches the $G$ allele. The nonspecific amplification results from mismatch extension from the $\mathrm{A}$ allele. When this occurs, it results in an efficient substrate for further amplification. The thickness and position of the arrow represent the amplification efficiency in each cycle. (B) The specific amplification of PAP from the G allele occurs at high efficiency. Two types of nonspecific amplifications originate from the A allele: (i) nonspecific am plification can occur at low efficiency by mismatch pyrophosphorolysis resulting in a A:T homoduplex PU:UP product, which is not an efficient template for subsequent amplification; and ( $i i)$ nonspecific am plification can occur at extremely low efficiency by both mismatch pyrophosphorolysis and misincorporation to produce a G:T heteroduplex PU:UP product, but once it occurs, it provides an efficient template for subsequent amplification. A similar tendency of nonspecific amplifications is suggested for linear amplification by PAP with only $\mathrm{D}_{5} \mathrm{G}^{*}$. It should be noted that the allele-specific nucleotide of $\mathrm{P}^{*}$, such as $\mathrm{D}_{3} \mathrm{G}^{*}$, may be near but not at the $3^{\prime}$ terminus. In that case, nonspecific amplification of PAP requires mismatch pyrophosphorolysis and mismatch extension. While both variations of PAP should have higher specificity than PASA, the highest specificity is predicted when the $3^{\prime}$ terminal dideoxynucleotide is also the allele-specific nucleotide.
GNCCPy-3'/3'-PyCCNG GPu- $^{\prime}$ ) has a restriction site within the PU:UP duplex. The GG alleles were amplified by PAP with $\mathrm{D}_{5} \mathrm{G}^{*}$ and $\mathrm{U}$; PCR amplification with $\mathrm{D}_{1}$ and $\mathrm{U}$ was used as the control. Forty microliters of the PAP reaction and $2 \mu \mathrm{L}$ PCR were purified and concentrated with a Centricon 100 microconcentrator, and the products were digested by the restriction endonuclease: $2.5 \mathrm{U}$ AciI in $1 \times \mathrm{NE}$ buffer 3 , or $3 \mathrm{U} E a e \mathrm{I}$ in $1 \times \mathrm{NE}$ buffer 1 or 30 U Eco0109I in NE buffer 4 with BSA (all the above enzymes and buffers are from New England Biolabs, Beverly, MA, USA). The reaction $(10 \mu \mathrm{L})$ was incubated at $37^{\circ} \mathrm{C}$ for $2 \mathrm{~h}$, and the digestion reaction was electrophoresed through a standard $2 \%$ agarose gel as described above.

\section{RESULTS}

\section{Principle of PAP}

$T f l$ and $T a q$ DNA polymerases were shown to contain pyrophosphorolysis activity (data not shown). Tfl DNA polymerase was utilized to detect the $\mathrm{G}$ allele at nucleotide 229 of the $\mathrm{D}$ dopamine receptor gene (11) (Figure 1A). $\mathrm{P}^{*}$ was synthesized with either ddG or ddA at the $3^{\prime}$ terminus (see Table 1). The $3^{\prime}$ terminal dideoxynucleotide inhibits direct extension by polymerization but can be removed by pyrophosphorolysis in the presence of $\mathrm{PP}_{\mathrm{i}}$ when the $\mathrm{P}^{*}$ is specifically hybridized with the complementary strand of the $\mathrm{G}$ allele. The degraded oligonucleotide can be extended by polymerization in the $5^{\prime} \rightarrow 3^{\prime}$ direction (Figure 1, B and C).

The enhanced specificity of PAP relative to PASA is provided by serially coupling pyrophosphorolysis and polymerization. Significant nonspecific am plification requires mismatch pyrophosphorolysis and misincorporation by DNA polymerase, which is an extremely rare event (Figure 2).

\section{Specific Amplification with $\mathrm{D}_{5} \mathrm{G}^{*}$ and $D_{3} G^{*}$}

PAP was performed with two oligonucleotides ( $\mathrm{P}^{*}$ and $\left.\mathrm{U}\right), T f l$ DNA polymerase and DNA template of the 
GG and AA alleles. Multiple P* were tested (Table 1). The allele-specific nucleotide and dideoxynucleotide co-localized to the $3^{\prime}$ terminus $\left(D_{5} G^{*}\right)$ and the allele-specific nucleotide two bases from the $3^{\prime}$ terminus $\left(D_{3} G^{*}\right)$ specifically amplified the $G$ allele in the presence of $\mathrm{PP}_{\mathrm{i}}$ (Figure $3 \mathrm{~A}$ ). Without added $\mathrm{PP}_{\mathrm{i}}$, no specific product was observed with $\mathrm{D}_{5} \mathrm{G}^{*}$, indicating that added $\mathrm{PP}_{\mathrm{i}}$ was an essential component for PAP (Figure $3 \mathrm{~B}$, lanes 6 and 15). Faint products with $\mathrm{D}_{3} \mathrm{G}^{*}$ in lane 4 and with $\mathrm{D}_{4} \mathrm{G}^{*}$ in lane 5 were observed ( Figure 3B) (see Discussion).

Effects of $\mathbf{p H}$, Concentration of $\mathrm{PP}_{\mathbf{i}}$ and Concentration of $\mathrm{dNTP}$ and Enzyme

Each of above parameters was examined. PAP was most efficient at $\mathrm{pH}$ between 7.4 and 7.7, at $\mathrm{PP}_{\mathrm{i}}$ concentration between 200 and $400 \mu \mathrm{M}$ and at dNTPs concentrations between 25 and $50 \mu \mathrm{M}$ (Table 2). Taq DNA polymerase can substitute for $T f l$ with similar efficiencies (Table 2).

\section{Identity of Specific Products}

To confirm the identity of the specific products, restriction endonuclease digestion was performed (Figure 4). Each of the three restriction endonucleases of AciI, EaeI and Eco0109I has a restriction site within the PU:UP duplex. The expected restriction fragments were found. Similar results were observed with $\mathrm{D}_{3} \mathrm{G}^{*}$ and $\mathrm{U}$ (data not shown).

The specific products of PAP with $\mathrm{D}_{5} \mathrm{G}^{*}$ and $\mathrm{U}$ revealed two specific bands on the agarose gel (i.e., PU:UP

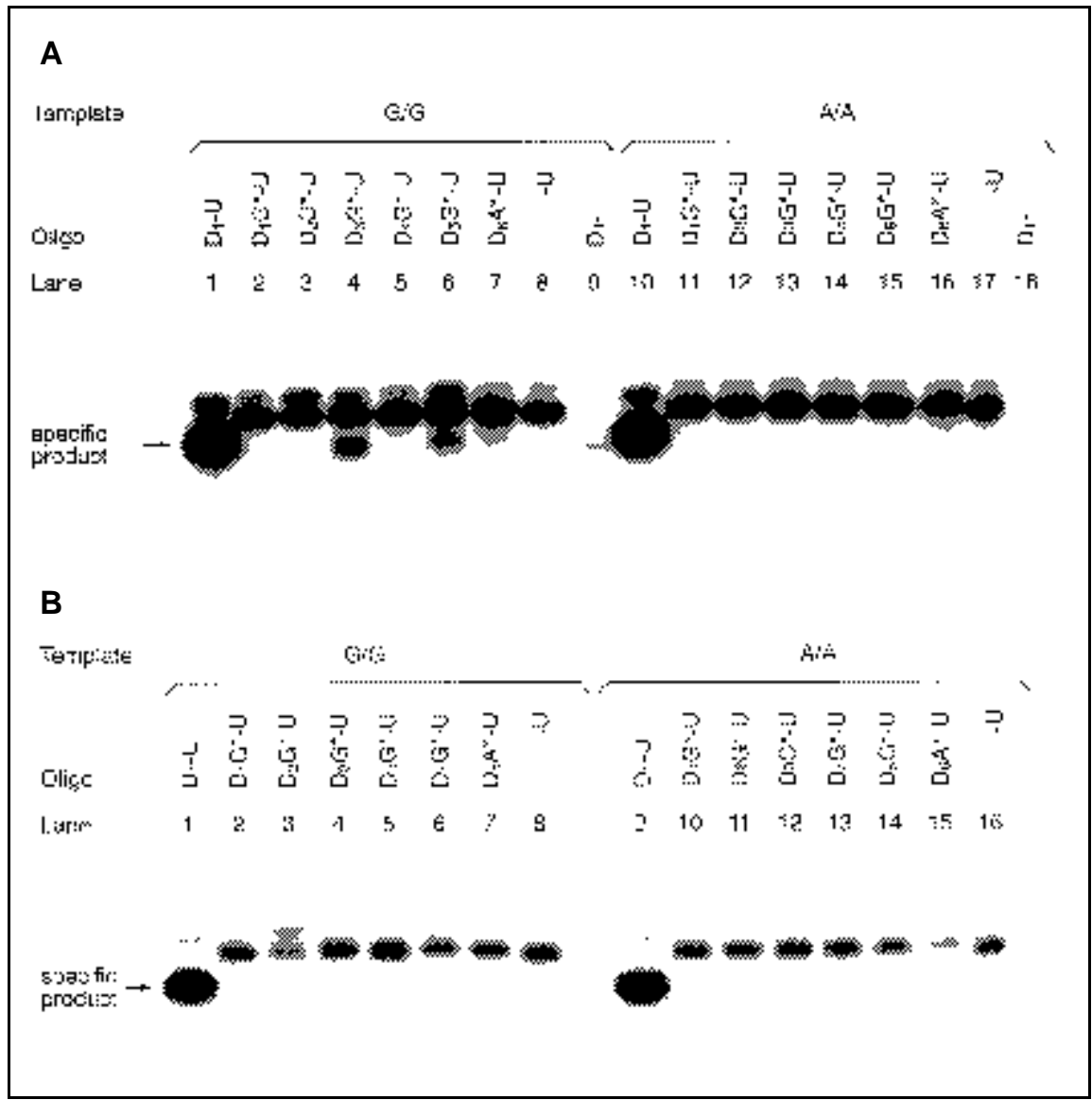

Figure 3. Specific amplification with $\mathrm{DG}_{\mathbf{3}} *$ and $\mathrm{D}_{\mathbf{3}} \mathbf{G}^{*}$. PAP was performed in the presence $(\mathrm{A})$ or the absence (B) of added $\mathrm{PP}_{\mathrm{i}}$ with two oligonucleotides for exponential amplification. The oligonucleotides are listed in Table 1. Extension controls with only U identify the positions of TU:UT and UT. Extension controls with D identify the position of PU. PCR controls of D and U identify the positions of PU:UP and PU:UT. Only $20 \%$ of the extension product with $\mathrm{D}$ and the PCR product with D and $\mathrm{U}$ was loaded relative to other lanes. and UP), because U was more efficient than $\mathrm{D}_{5} \mathrm{G}^{*}$ under our amplification conditions. To confirm this, the GG alleles were amplified by PAP using $T f l$ DNA polymerase with $\mathrm{D}_{5} \mathrm{G}^{*}$ and $\mathrm{U}$ as was done previously. The products were denatured and electrophoresed through a denaturing polyacrylamide gel. Only one specific band in singlestranded form was observed, indicating that the specific PAP products contain the duplexed and single-stranded segments. The same result was observed with $\mathrm{D}_{3} \mathrm{G}^{*}$ and $\mathrm{U}$ (data not shown).

\section{Linear PAP}

PAP was performed for linear amplification with only one $\mathrm{P} *$ from the $\mathrm{GG}$ and AA alleles in the presence of $\mathrm{PP}_{\mathrm{i}}$. The specific products of PAP were obtained with $\mathrm{D}_{3} \mathrm{G}^{*}$ and with $\mathrm{D}_{5} \mathrm{G}^{*}$, but not with the other $\mathrm{P}^{*}$ (Figure 5, lanes 4 and 6). The efficiency of $\mathrm{P}^{*}$ was affected by the oligonucleotide size, the $3^{\prime}$ terminal dideoxynucleotide and the position of the allele-specific nucleotide.

\section{DISCUSSION}

\section{Enhanced Specificity of PAP with $\mathbf{D}_{\mathbf{5}} \mathbf{G} *$}

PAP relies on the serial coupling of the two reactions, each with high specificity. A mutation-specific $\mathrm{P}^{*}$ is activated by pyrophosphorolysis on the mutated template; the extended fidelity product contains the mutation. In the presence of wild-type template, pyrophosphorolysis occurs inefficiently because the $3^{\prime}$ terminus of $\mathrm{P}^{*}$ does not match; the extended fidelity product will contain the wild type sequence. For the extended product to contain the specific mutation, a specific incorporation error is also required.

Evidence is presented that pyrophosphorolysis followed by polymerization may be used to increase the specificity of PASA. Significant nonspecific amplification requires the serial coupling of the two types of errors (Figure 2). The mismatch pyrophosphorolysis rate to remove a mismatch deoxynucleotide at the $3^{\prime}$ terminus, expressed as the removal rate of an incorrect versus a correct dNMP, was report- 
form and trigger nonspecific pyrophosphorolysis of $\mathrm{P}^{*}$ in later cycles, with $\mathrm{PP}_{\mathrm{i}}$ released from the by-polymerization or with $\mathrm{PP}_{\mathrm{i}}$ contaminated in dNTPs. $3^{\prime}$ terminal degraded $\mathrm{D}_{3} \mathrm{G}^{*}$ and $\mathrm{D}_{4} \mathrm{G}^{*}$ can be hybridized and extended as false signal. Oligonucleotide dimers were observed with $\mathrm{D}_{3} \mathrm{G}^{*}$ and $\mathrm{D}_{4} \mathrm{G}^{*}$ (data not shown). Another possibility with $D_{3} G^{*}$ is that the specific pyrophosphorolysis can occur in later cycles with $\mathrm{PP}_{i}$ released or with $\mathrm{PP}_{\mathrm{i}}$ contaminated. A third possibility is that $D_{3} G^{*}$ and $D_{4} G^{*}$ were contaminated by minimal $\mathrm{D}_{3}$ and $\mathrm{D}_{4}$, which did not have $\mathrm{G}$ dideoxynucleotide at $3^{\prime}$ termini.

\section{Comparison with Other \\ Technologies}

A number of methods for enzymatic nucleic acid amplification in vitro have been developed and can be adapted to detect known sequence variants. These include PCR $(18,19)$, ligase chain reaction (LCR) $(2,10)$ and rolling circle amplification (RCA) $(1,12)$. PAP is different in many ways: (i) pyrophosphorolysis and polymerization are serially coupled for each amplification; (ii) there is at least one dideoxyoligonucleotide for PAP. Other chemically modified nucleotides lacking the $3^{\prime}$ hydroxyl group at the $3^{\prime}$ terminus can serve the same function; (iii) one format is for linear amplification and the other is for exponential amplification; (iv) $\mathrm{PP}_{\mathrm{i}}$ is necessary for the amplification; (v) significant nonspecific amplification requires both mismatch pyrophosphorolysis and misincorporation; and (vi) PAP can detect known point mutations and may greatly increase the specificity to detect an extremely rare mutant allele from the wild-type allele.

The mechanistic basis is that two or more reactions are serially coupled for amplification with increased specificity. The key component of PAP is $\mathrm{P}^{*}$. The blocked $3^{\prime}$ terminus in these experiments is a dideoxynucleotide, but any nonextendable nucleotide susceptible to pyrophosphorolysis could, in principle, be substituted. Indeed, any enzyme that cleaves an oligonucleotide $5^{\prime}$ to a mismatch could serve the same function as pyrophosphorolysis activation. For example, a blocked oligonucleotide including the methylated recognition sequence (such as Gn ATC) is annealed to its target with the unmethylated recognition sequence, then restriction endonuclease (such as $D p n I$ ) can only cleave the methylated site and so activate the oligonucleotide for extension.
If a mismatch is located $5^{\prime}$ to the cleavage site, significant nonspecific amplification requires the serial coupling of mismatch cleavage and a misincorporation, which is a rare event. Activatable oligonucleotides may also be combined

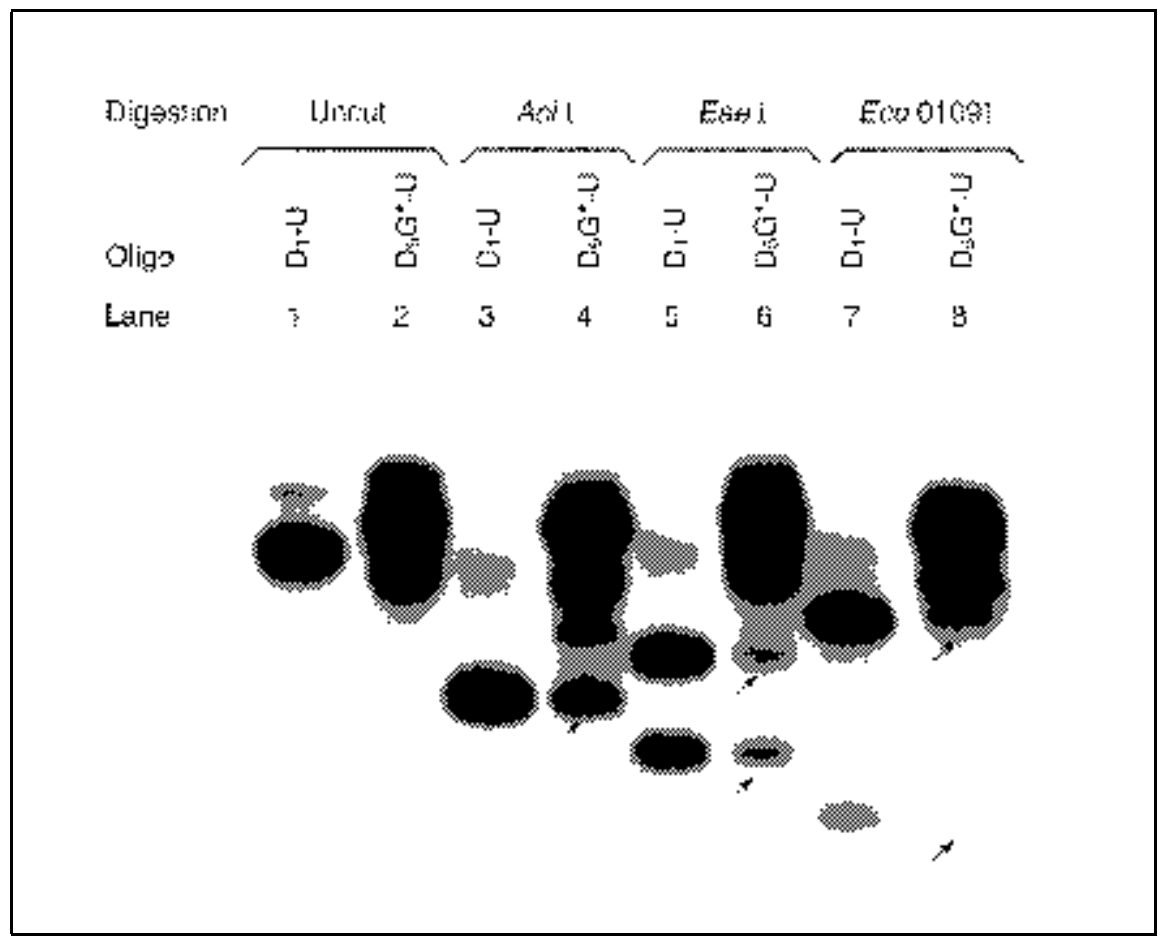

Figure 4. Restriction endonuclease digestion. To show specificity of PAP, samples from the experiment shown in Figure 3 were digested with AciI, EaeI and Eco0109I restriction endonucleases. Each enzyme has a restriction site within PU:UP. PAP amplified the GG alleles with $\mathrm{D}_{5} \mathrm{G}^{*}$ and $\mathrm{U}$. Five percent of PCR product with $\mathrm{D}$ and $\mathrm{U}$ were taken as control. AciI produces a 236- and a 233-bp fragment from PU:UP and a 407- and a 233-bp fragment from TU:UT. EaeI produces a 289- and a 180-bp fragment from PU:UP and a 460- and a 180-bp fragment from TU:UT. Eco0109I produces a 348- and a 121-bp fragment from PU:UP and a 107-, a 412- and a 121-bp fragment from TU:UT. The arrows indicate the digestion products expected from PU:UP.

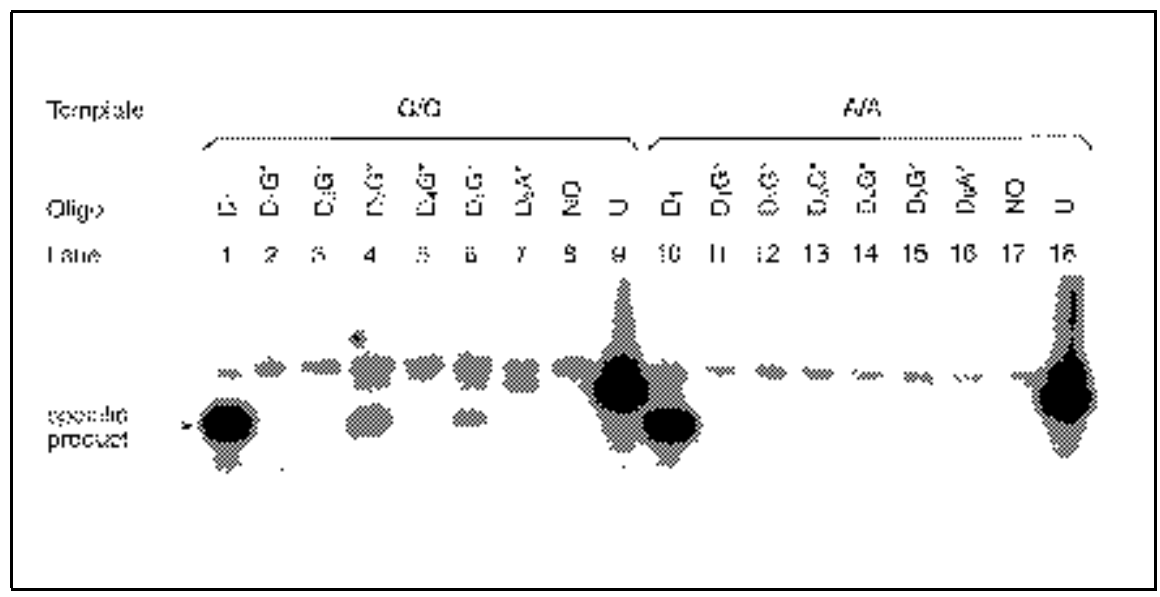

Figure 5. Linear PAP. PAP was performed with only one $\mathrm{P}^{*}$ in the presence of added $\mathrm{PP}_{\mathrm{i}}$. Twenty percent of the extension product with $\mathrm{D}$ was loaded relative to other lanes (lanes 1 and 10). No = no oligonucleotide added. 
with "minisequencing" primer extension. This may provide a more specific assay for detection of single-base changes that might be particularly amenable to chip technology in which specificity can be a problem (22). Demonstration that PAP can occur in the linear format (Figure 5) supports the feasibility of this approach.

In summary, a novel method of PAP has been developed. In PAP, pyrophosphorolysis and polymerization by DNA polymerase are coupled serially for each amplification by using $\mathrm{P}^{*}$. PAP can be applied for exponential amplification or for linear amplification. Various parameters, including allelic tem plate, $\mathrm{P}^{*}$ sequence, DNA polymerase, $\mathrm{pH}, \mathrm{PP}_{\mathrm{i}}$ and $\mathrm{dNTP}$ concentration, were examined. PAP, adapted for detection of the polymorphism in the $\mathrm{D}_{1}$ dopamine receptor gene, is a promising approach for detection of rare mutations.

\section{REFERENCES}

1.Banér, J., M. Nilsson, M. Mendel-Hartvig and U. Landegren. 1998. Signal amplification of padlock probes by rolling circle replication. Nucleic Acids Res. 26:5073-5078.

2.Barany, F. 1991. Genetic disease detection and DNA amplification using cloned thermostable ligase. Proc. Natl. Acad. Sci. USA 88:189-193.

3.Bebenek, K., C.M. Joyce, M.P. Fitzgerald and T.A. Kunkel. 1990. The fidelity of DNA synthesis catalyzed by derivatives of $E s$ cherichia coli DNA polymerase I. J. Biol. Chem. 265:13878-13887.

4.Chien, A., D.B. Edgar and J.M. Trela. 1976. Deoxyribonucleic acid polymerase from the extreme thermophile Thermus aquaticus. J. Bacteriol. 127:1550-1557.

5.Duetcher, M.P. and A. Kornberg. 1969. Enzymatic synthesis of deoxyribonucleic acid. 28 . The pyrophosphate exchange and pyrophosphorolysis reactions of deoxyribonucleic acid polymerase. J. Biol. Chem. 244:30193028.

6.Eckert, K.A. and T.A. Kunkel. 1990. High fidelity DNA synthesis by the Thermus aquaticus DNA polymerase. Nucleic Acids Res. 18:3739-3744.

7.Kaledin, A.S., A.G. Sliusarenko and S.I. Gorodetskii. 1981. Isolation and properties of DNA-polymerase from the extreme thermophilic bacterium Thermus flavus. Biokhimiia 46:1576-1584

8.Knoll, A., R.P. Ketterling and S.S. Sommer. 1996. Absence of somatic mosaicism in 17 families with hemophilia B: an analysis with a sensitivity 10 - to 1000 -fold greater than that of sequencing gels. Hum. Genet. 98:539-545.

9.Kornberg, A. and T.A. Baker. 1992. DNA Replication, 2nd ed., p.113-226. W.H. Free- man and Company, New York.

10.Landegren, U., R. Kaiser, J. Sanders and L. Hood. 1988. A ligase-mediated gene detection technique. Science 241:1077-1080.

11.Liu, Q., J.L. Sobell and S.S. Sommer. 1995. Screening the dopamine D1 receptor gene in 131 schizophrenics and eight alcoholics: identification of polymorphisms but lack of functionally significant sequence changes. Am. J. Med. Genet. (Neuropsych. Genet.) 60:165171.

12.Lizardi, P.M., X. Huang, Z. Zhu, P. BrayWard, D.C. Thomas and D.C. Ward. 1998. Mutation detection and single-molecule counting using isothermal rolling-circle am plification. Nat. Genet. 19:225-232

13.Longley, M.J., S.E. Bennett and D.W. Mosbaugh. 1990. Characterization of the $5^{\prime}$ to $3^{\prime}$ exonuclease associated with Thermus aquaticus DNA polymerase. Nucleic Acids Res. 18:7317-7322.

14.Maniatis, T., E.F. Fritsch and J. Sambrook. 1982. Molecular Cloning: A Laboratory Manual. CSH Laboratory Press. Cold Spring Harbor, NY.

15.Miyada, C.G. and R.B. Wallace. 1987. Oligonucleotide hybridization techniques. Methods Enzymol. 154:94-107.

16.Parsons, B.L. and R.H. Heflich. 1997. Genotypic selection methods for the direct analysis of point mutations. Mutat. Res. 387:97-121.

17.Pourzand, C. and P. Cerutti. 1993. Genotypic mutation analysis by RFLP/PCR. Mutat. Res. 288:113-121.

18.Saiki, R.K., D.H. Gelfand, S. Stoffel, S.J. Scharf, R. Higuchi, G.T. Horn, K.B. Mullis and H.A. Erilich. 1988. Primer-directed enzymatic amplification of DNA with a thermostable DNA polymerase. Science 239:487491.

19.Saiki, R.K., S. Scharf, F. Faloona, K.B. Mullis, G.T. Horn, H.A. Erlich and N. Arnheim. 1985. Enzymatic amplification of betaglobin genomic sequences and restriction site analysis for diagnosis of sickle cell anemia. Science 230:1350-1354.

20.Sanger, F., S. Nichlen and A.R. Coulson. 1977. DNA sequencing with chain-terminating inhibitor. Proc. Natl. Acad. Sci. USA 75:5463-5467.

21.Sarkar, G., J. Cassady, C.D.K. Bottema and S.S. Sommer. 1990. Characterization of polymerase chain reaction amplification of specific alleles. Anal. Biochem. 186:64-68.

22.Syvanen, A.C. 1999. From gel to chips: "minisequencing" primer extension for analysis of point mutations and single nucleotide polymorphisms. Hum. Mutat. 13:1-10.

23.Tabor, S. and C.C. Richardson. 1990. DNA sequence analysis with a modified bacteriophage T7 DNA polymerase. J. Biol. Chem. 265:8322-8328.

24.Tabor, S. and C.C. Richardson. 1995. A single residue in DNA polymerases of the Escherichia coli DNA polymerase I family is critical for distinguishing between deoxy- and dideoxyribonucleotides. Proc. Natl. Acad. Sci. USA 92:6339-6343.

25.Vander Horn, P.B., M.C. Davis, J.J. Cunniff, C. Ruan, B.F. McArdle, S.B. Samols, J. Szasz, G. Hu et al. 1997. Thermo Sequenase ${ }^{\mathrm{TM}}$
DNA polymerase and T. acidophilum pyrophosphatase: new thermostable enzymes for DNA sequencing. BioTechniques 22:758-762.

26.Wong, I., S.S. Patel and K.A. Johnson. 1991. An induced-fit kinetic mechanism for DNA replication fidelity: direct measurement by single-turnover kinetics. Biochemistry 30:526-537.

Received 21 March 2000; accepted 5 July 2000 .

Address correspondence to:

Dr. Steve S. Sommer

Director, Departments of Molecular Genetics and Molecular Diagnosis

City of Hope National Medical Center

1500 East Duarte Road

Duarte, CA 91010-3000, USA

e-mail:ssommer@coh.org 